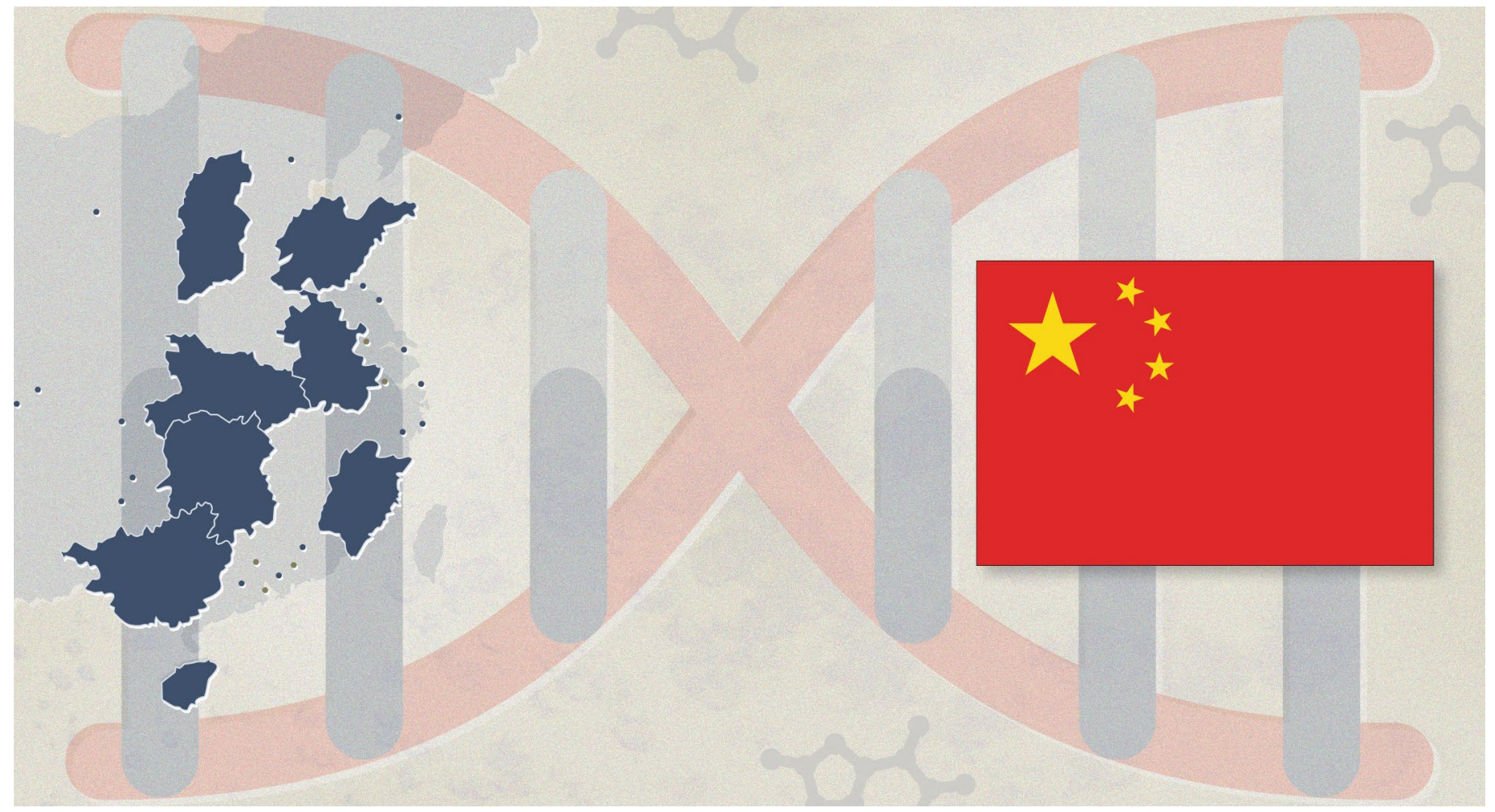

\title{
China at the threshold
}

China's growing influence in biotech was underscored in 2020 during a record-breaking year for sector financing.

\section{Melanie Senior}

020 will be remembered in biotechbut not just for the response to the pandemic. Biotech financing went off the charts, with initial public offerings (IPOs), follow-on offerings and private investment breaking new records (Box 1 and Table 1). Although some whisper warnings of a bubble, others continue to say the pandemic has simply accelerated biotech's graduation to a 'new normal', with more funding and greater prominence across a wider range of investor portfolios.

Behind the record-breaking numbers is a force that will endure into 2021 and beyond: the rise of China's innovative biotech sector. Chinese companies accounted for over a third of global biotech IPOs in 2020, up from a quarter the previous year. China's stock exchanges hosted six of the top ten largest IPOs globally (Fig. 1 and Table 2). Western regulators, including the US Food and Drug Administration (FDA), are starting to welcome Chinese-developed products.
Put that together with a growing domestic market that is increasingly receptive to innovative therapies, and the landscape for global biotech is radically changing.

\section{Going to plan}

Chinese healthcare is no longer only about domestic manufacturing, state-owned enterprises and traditional medicines or copycat Western drugs. A fast-growing cohort of Chinese biotechs is developing differentiated medicines, not just for the large and increasingly innovation-friendly home market, but for the United States and other Western nations. FDA officials are increasingly willing to accept drug data gathered in China. The first China-developed cancer drug, BeiGene's Brukinsa (zanubrutinib, an oral small-molecule Bruton's tyrosine kinase (BTK) inhibitor for mantle cell lymphoma), was approved in the United States in late 2019; a handful of others have received FDA
Fast Track or Breakthrough designation or are approaching submission.

Investment in Chinese biotech reflects its growing global relevance. The $\$ 8$ billion raised in stock exchange listings by Chinese biotechs easily overshadowed European companies' $\$ 1.3$ billion haul. Most of the Europeans' money was raised on Nasdaq rather than on domestic exchangesGermany's mRNA vaccine maker CureVac secured one of the country's largest IPOs on Nasdaq in August 2020 (Box 2). Nasdaq's large specialist investor base continues to attract the most innovative companies wherever they are based.

China's momentum has continued into 2021. The country was home to three of the top ten biotech IPOs in the first four months of the year. Two Chinese companies, Taicang-based Connect BioPharma and Suzhou-based cell therapy player Gracell Biotechnologies, made the top ten Nasdaq biopharma IPOs during the period (Table 3). 


\section{Box 1 | The numbers beyond China}

This report is based on a Nature Biotechnology survey on public biotech companies that has been published in the journal using a similar methodology since 1996. Each year, we gather data on research-driven IPOs (Supplementary Table 1) and segment the company financials according to market cap. This year's sector showed a large increase in the number of IPOs (up several-fold from 2019 in both number of IPOs and average amount raised; see figure, panel a). There was also a more than doubling in the number of large cap companies-from 32 in 2019 to 67 in 2020 (panel b), fueled by a global frothy public market. Much of the gains in some of the new large caps have already been lost, while the mainstays of this group have remained steady-with the recent exception of Biogen, whose shares soared following FDA approval of Alzheimer's treatment Aduhelm (aducanumab).

Revenues across the board enjoyed a $17 \%$ increase over 2019-fueled in part by outsized increases by COVID-19-related programs-with a concomitant increase in $\mathrm{R} \& \mathrm{D}$ spending of $21 \%$ in the group (panel c). These numbers show the same trends as 2019's, which was another very good year for the sector.
The data in Supplementary Table 1 were provided by consultants Ernst \& Young. Our definition of what constitutes a biotech company, which has changed somewhat with the industry, includes R\&D-driven companies built on applications of biological organisms, systems or processes, or on the provision of specialist services that facilitate biological understanding. We exclude pharmaceutical companies, medical device firms and contract research organizations to better focus on the unique attributes and situations that make up the research-driven biotech sector. a

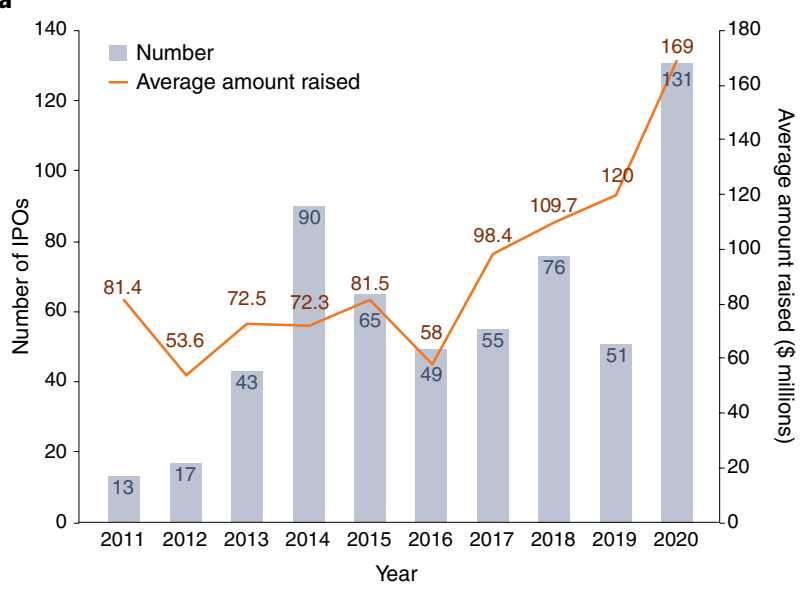

b

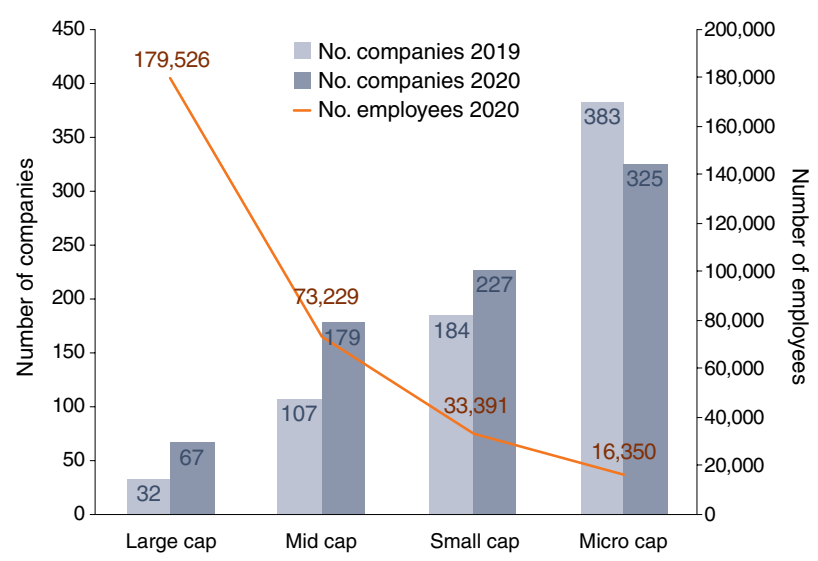

C

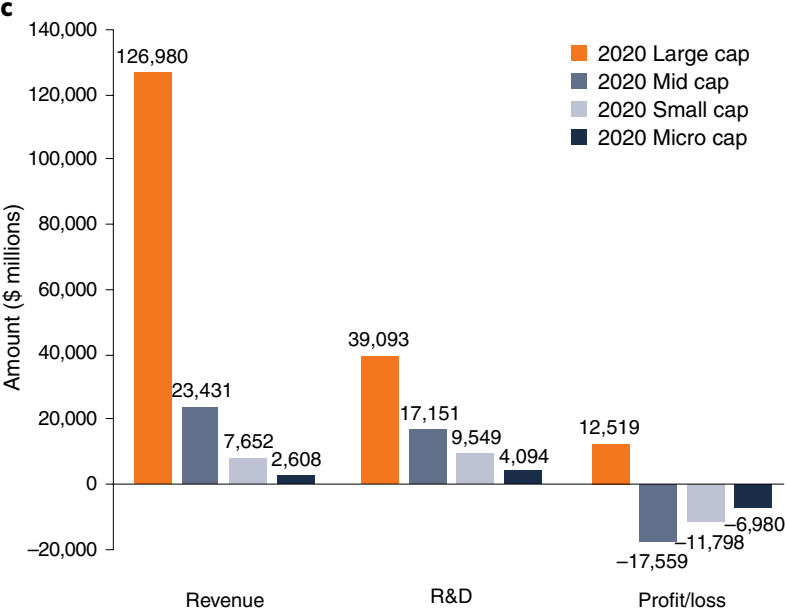

Public biotech barometers. a, IPO activity since 2011, showing amount raised and number of companies floated. $\mathbf{b}$, Number of companies and employees by market cap. Large cap, $>\$ 5$ billion; mid-cap, $\$ 1$ billion to $\$ 5$ billion; small cap, $\$ 250$ million to $\$ 1$ billion; microcap, $<\$ 250$ million. $\mathbf{c}$, Public biotech company revenue, $R \& D$ spending, net profits and loss.

This strong showing is all part of the Chinese government's plan. China's leaders are supporting local innovators with funding, an expanding public market infrastructure, streamlined regulatory processes and a health system that is starting to reimburse newer drugs. China is brimming with smart, hard-working, inexpensive scientists and engineers; 
Table 1 | Financings in 2019 versus 2020

\begin{tabular}{lll} 
Type of financing & $\mathbf{2 0 1 9}$ (\$ billions) & $\mathbf{2 0 2 0}$ (\$ billions) \\
\hline IPO & 8.2 & 23.6 \\
Follow-on & 22.9 & 42.8 \\
PIPEs & 2.8 & 10.7 \\
\hline
\end{tabular}

Source: BioCentury BCIQ

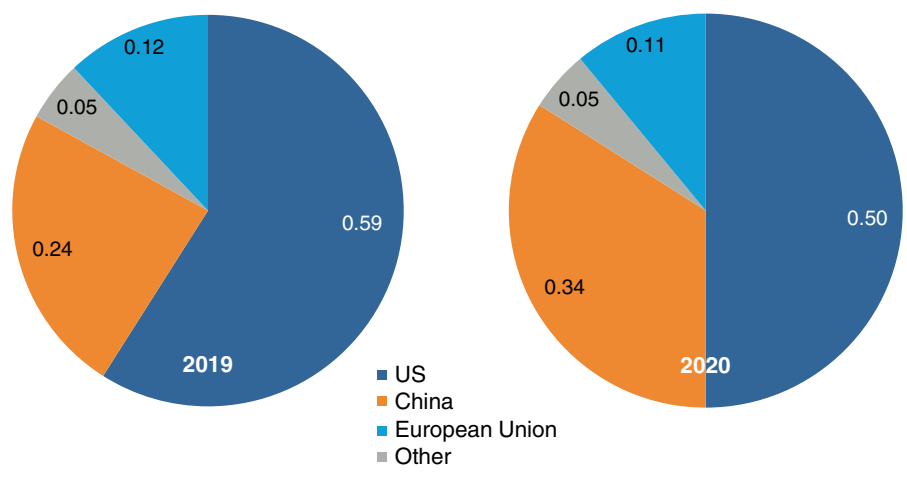

Fig. 1 | Biotech 2020 IPOs by region. Source: BioCentury BCIQ.

about $80 \%$ of Chinese scientists living abroad have returned in the past decade, boosting home-grown research. China's 1.4-billion-strong population is getting wealthier and older, and succumbing to similar chronic conditions as in the Westexacerbated by high rates of smoking, pollution and poor healthcare in rural areas. In 2020, a quarter of all newly diagnosed cancers and nearly a third of cancer-related deaths were in China.

Some of China's new biotechs are set up to serve and provide Western partners with access to the world's second-largest biopharma market (Table 4). Amgen has established a $20.5 \%$ stake in the Chinese sector flagship BeiGene in Beijing. Shanghai-based JW Therapeutics was co-founded by Juno Therapeutics (now part of Bristol Myers Squibb) and contract research organization WuXi AppTec to develop cellular immunotherapies for Chinese patients. JW's lead product, relmacabtagene autoleucel, an anti-CD19 CAR-T cell therapy for relapsed or refractory B-cell lymphoma, has priority review and hopes to be the first such cellular therapy on the local market. JW raised over $\$ 335$ million in a November 2020 IPO in Hong Kong-only narrowly outside the top ten global biotech listings. In May 2020, Pfizer invested \$200 million in five-year-old CStone Pharmaceuticals, accessing late-stage product sugemalimab (an IgG1 monoclonal antibody (mAb) targeting programmed cell death 1 ligand, or PD-L1) and obtaining a development and marketing partner for other oncology drugs in China.
But for many innovation-focused Chinese biotechs and their investors, the domestic market isn't enough. Healthcare coverage, while growing, remains limited. Prices are low. Programmed death-1 (PD1) inhibitors for cancer-among the first targeted medicines to be reimbursed on China's National Drug Reimbursement List, in 2019-now cost up to $80 \%$ less than in the United States. That's in part because several market entrants have created price competition, but even a first-in-class drug could not command anything near US prices. In per capita income terms, China remains a poor country.

Hence China's biotechs need to go global. "We've never designed [targeted therapies] only for China," says Christian Hogg, CEO of Hong Kong-based Hutchmed (formerly Hutchison China MediTech). The company was among the first biotechs to set up in China, in 2000, back when "there was not biotech sector at all," recalls Hogg. Hutchmed sells two drugs in China: Elunate (fruquintinib), a selective small-molecule inhibitor of vascular endothelial growth factor receptors (VEGFR) 1, 2 and 3 for metastatic colorectal cancer (partnered with Eli Lilly); and Sulanda (surufatinib), a selective small-molecule inhibitor of VEGFR, fibroblast growth factor receptor and colony stimulating factor- 1 receptor for advanced non-pancreatic neuroendocrine tumors. It is now building its US commercial infrastructure, using some of the $\$ 300$ million raised via private investments in public equity (PIPEs) over the past 12 months. The company is dual listed on Nasdaq and AIM in the United Kingdom. Sulanda completed its rolling submission to the US FDA in May 2021 and a global phase 3 trial of Elunate is underway.

\section{Evolving innovation and efficiency}

Few of China's biotechs have dived straight into developing novel drugs, let alone novel drugs targeting new biology. Many have a stash of biosimilars, and almost all are chasing well-established targets. That's why cancer is in the hotspot: immuno-oncology offers plenty of validated targets and opportunities to create molecules and combinations that can be differentiated on efficacy, toxicity, indication or position in the treatment pathway.

Yet behind the near-term pipelines of biosimilars or me-toos, "we're starting to see true fast followers that launch within 1-2 years of the first-in-class," says Jay Lee, a Hong Kong-based equity analyst at Morningstar. Some groups are chasing best-in-class, adds Simone Song, founder and senior partner at Hong Kong-based venture capital firm ORI Capital.

This evolution from biosimilars and me-toos to differentiated drugs may give Chinese biotechs a speed and efficiency edge. "Some China-born biotechs have an advantage over foreign companies: a domestic R\&D base bringing more competitive, affordable drugs," says Michael $\mathrm{Xi}, \mathrm{CFO}$ at Zhongshan-based Akeso, which raised \$330 million in its Hong Kong debut in April 2020. Akeso expects to file the PD-1/cytotoxic T lymphocyte antigen 4 (CTLA-4)-targeting tetrameric human IgG1 bispecific mAb cadonilimab (AK104) in China this year and is running a registrational trial in cervical cancer in the United States, where the antibody has breakthrough designation from the FDA.

Newer modalities like bispecific mAbs or CAR-T technologies offer the prospect of large global rewards-and there's less catching up to do. Indeed, in CAR-T cells, China is globally competitive thanks to low-cost manufacturing and the technology's classification as a medical device, which accelerates regulatory approvals domestically. Gracell is, like JW Therapeutics, chasing next-generation CAR-T therapies that are faster to make than current ones and cheaper. Supported by top US and Chinese venture capital firms, including OrbiMed and Shanghai-based 5Y Capital (formerly Morningside Venture Capital), plus \$240 million from its outsized Nasdaq listing in January 2021, Gracell is hoping to use Chinese clinical data to win US approvals.

"Technologies have advanced to the point where if we understand the target 


\section{Table 2 | Top ten 2020 IPOs}

\begin{tabular}{llll} 
Company & $\begin{array}{l}\text { Amount raised } \\
\text { (\$ millions) }\end{array}$ & Date completed & Exchange \\
\hline RemeGen & 591 & 9 November & Hong Kong \\
\hline AbCellera Biologics & 555 & 15 December & Nasdaq \\
\hline Everest Medicines & 519 & 8 October & Hong Kong \\
\hline Legend Biotech & 487 & 5 June & Nasdaq \\
\hline Relay Therapeutics & 460 & 15 July & Nasdaq \\
\hline Genor Biopharma & 402 & 6 October & Hong Kong \\
\hline Akeso & 383 & 23 April & Hong Kong \\
\hline Antengene & 366 & 19 Nov & Hong Kong \\
Gan \& Lee Pharmaceuticals & 360 & 28 June & Shanghai \\
\hline Atea Pharmaceuticals & 345 & 3 November & Nasdaq \\
\hline
\end{tabular}

Source: BioCentury BCIQ

\section{Box 2 | Will 2020 spark a German revival?}

Could the success of BioNTech's COVID-19 mRNA vaccine partnership with Pfizer spark the German biotech sector into life? Despite producing innovative companies, the country still desperately lacks local specialist investors.

The pandemic has projected two German biotech firms specializing on mRNA vaccines into the headlines. Back in 2019, Mainz-based BioNTech limped onto Nasdaq with a smaller-than-expected IPO. Now, with its Pfizer-partnered mRNA-based SARS-CoV-2 vaccine on track to reap $\$ 26$ billion this year, BioNTech sports a market capitalization of $\$ 58$ billion-more than that of biotech pioneer Vertex Pharmaceuticals, with its four marketed medicines.

Tübingen-based CureVac's most exciting program before the pandemic was a phase 1 rabies vaccine candidate. In 2020, once the value of its mRNA technology and expertise became clearand following an overture from then-US President Trump's team-it was showered with German government funding. CureVac raised $\$ 640$ million in a private round in July (with investors including the German government, GlaxoSmithKline and the Qatar Investment Authority), then another \$245 million on Nasdaq the following month. In February 2021 it began a rolling submission at the European Medicines Agency for its COVID-19 vaccine candidate, which can be stored in the fridge.

Could this duo provide the catalyst that Germany needs to bring its biotech industry back to life? They accounted for half of the country's record-breaking total biotech financing of $\$ 3.73$ billion in 2020 , according to consultancy Ernst \& Young. That was more than double the previous high, in 2018.

The pandemic has helped spark interest from the public and build confidence that the sector can actually deliver products, according to Regina Hodits, managing partner at Wellington Partners Life Sciences, a German venture capital firm. German biotech revenues grew $36 \%$ to $\$ 7.9$ (€6.5) billion, according to BIO Deutschland, the industry association, whereas R\&D spend collectively reached $\$ 3.0$ (€2.5) billion.

The German government promptly announced its $\$ 12.1(€ 10)$ billion investment in a 'Future Fund' to support innovative startups. But it looks a bit like a knee-jerk reaction. "We've been fighting for years to get venture capital on the [government's] agenda," bemoans one local investor. BioNTech and CureVac were both largely financed by wealthy individuals (the Struengmann brothers and Dietmar Hopp, respectively). Even these billionaires cannot support an entire sector.

The boom and bust of Germany's Neuer Markt growth exchange at the turn of the twenty-first century badly stung a first generation of retail and specialist investors. Over two decades later, it is unclear whether CureVac and BioNTech can lure in a fresh set of deep-pocketed specialists. Disappointing phase 3 results for CureVac's unmodified mRNA vaccine in June 2021 wiped $45 \%$ of its market value-a reminder that biotech remains a risky sector. The German term for venture capital is still 'risk capital'. biology and the effect of modulating it, we can affordably develop drugs with their own patent protection. China's booming sector has done that on every validated target in the industry," says Alexis Borisy, founder and CEO of EQRx, which has in-licensed at least two Chinese assets in its bid to bring more affordable drugs to the West. EQRx raised \$500 million in January 2021, after pulling in 2020's largest series A financing in the sector.

More efficient R\&D tools are emerging everywhere. Yet for now China's low-priced domestic market and a healthcare system less encumbered by legacy infrastructure, vested interests or margin expectations than that in the United States make it the most prominent exhibit for cheaper biologics.

\section{Western dealmakers warm to Chinese assets}

Western dealmakers, facing growing competition and price pressure at home, are increasingly drawn to Chinese-developed assets, especially in cancer. A quarter of 2020's licensing deals for R\&D-stage assets involved Chinese firms. In aggregate value, at $\$ 12.5$ billion, it was still a modest slice of the global pie, which increased by more than $60 \%$ during the pandemic year to over $\$ 100$ billion (Table 5). But China's share in 2020 was over a third higher than in 2019. Two of the top 20 deals by up-front value involved Chinese firms; there were none the previous year.

In August 2020, Lilly paid Suzhou-based partner Innovent Biologics \$200 million to develop and market the fully human IgG4 mAb PD-1 inhibitor Tyvyt (sintilimab) outside China. The companies co-developed the drug in China, where it became the first and only PD-1 inhibitor on the National Drug Reimbursement List in 2019 for relapsed or refractory Hodgkin's lymphoma.

Lilly now sees potential in the United States, too; sintilimab is in multiple clinical trials, including in combination with the big pharma's folate-targeting small molecule Alimta (pemetrexed) in non-squamous non-small-cell lung cancer. Meanwhile, Innovent has started a phase 1 US trial of its fully human bispecific IgG1 mAb targeting both CD47 and PD-L1.

Chinese biotech is also in the race for the best anti-CD47 mAb. In September 2020, AbbVie paid $\$ 180$ million up front for development and marketing rights outside Greater China to phase 1 lemzoparlimab, a fully human IgG4 anti-CD47 mAb from Shanghai-based I-Mab Biopharma. The antibody, vying for first-in-class status, hits the same transmembrane protein target as magrolimab, a humanized IgG4 anti-CD47 mAb at the heart of Gilead's 
Table 3 | Top 2021 IPOs

\begin{tabular}{llll} 
Company name & Country & $\begin{array}{l}\text { Amount raised (\$ millions) } \\
\text { (exchange) }\end{array}$ & $\begin{array}{l}\text { Date } \\
\text { completed }\end{array}$ \\
\hline Sana Biotechnology & United States & 676 (Nasdaq) & 3 February \\
Recursion Pharmaceuticals & United States & 502 (Nasdaq) & 16 April \\
Prestige Biopharma & Singapore & 405 (Korea) & 5 February \\
Instil Bio & United States & 368 (Nasdaq) & 18 March \\
Shanghai ZJ Bio-Tech & China & 326 (Shanghai) & 5 January \\
Immunocore & United Kingdom & 297 (Nasdaq) & 4 February \\
Hangzhou AllTest Biotech & China & 277 (Shanghai) & 12 March \\
Design Therapeutics & United States & 276 (Nasdaq) & 25 March \\
Bolt Biotherapeutics & United States & 264 (Nasdaq) & 4 February \\
Suzhou Basecare Medical & China & 259 (Hong Kong) & 5 February \\
Talis Biomedical & United States & 254 (Nasdaq) & 11 February \\
Cullinan Management & United States & 250 (Nasdaq) & 7 January \\
Gracell Biotechnologies & China & 240 (Nasdaq) & 8 January \\
Connect Biopharma & China & 220 (Nasdaq) & 18 March \\
\hline Source BioCenty Bcig & & & \\
\hline
\end{tabular}

Source: BioCentury BCIQ

\section{Box 3 | Mergers still to the fore}

M\&A totaled \$132 billion in 2020, including AstraZeneca's $\$ 39$ billion acquisition of Alexion Pharmaceuticals. The total was less than 2019's \$219 billion, which was inflated by Bristol Myers Squibb's giant $\$ 74$ billion acquisition of Celgene. As usual, M\&A was dominated by companies focusing on cancer and drugs for rare diseases. Gilead spent $\$ 27$ billion building up its oncology business in 2020, mostly on its acquisition of Immunomedics (\$21 billion), which has the antibodydrug conjugate Trodelvy (sacituzumab govitecan), a humanized $\operatorname{IgG} 1 \kappa \mathrm{mAb}$ targeting Trop- 2 connected to SN-38, the active metabolite of the topoisomerase 1 inhibitor chemotherapy irinotecan, through a cleavable linker.

Top ten M\&As in 2020

\section{Companies}

Alexion (seller)

AstraZeneca (buyer)

Immunomedics (seller)

Gilead Sciences (buyer)

Bristol Myers Squibb (buyer)

MyoKardia (seller)

Qiagen (seller)

Thermo Fisher Scientific (buyer)

Momenta Pharmaceuticals (seller) Johnson \& Johnson (buyer)

Forty Seven (seller)

Gilead Sciences (buyer)

Sanofi (buyer)

Principia Biopharma (seller)

Grail (seller)

Illumina (buyer)

Merck \& Co. (buyer)

VelosBio (seller)

Asklepios BioPharmaceutical (seller)

Bayer (buyer)

MYR (seller)

Gilead Sciences (buyer)

\section{Description}

AstraZeneca bids for Alexion; under

adjudication by UK regulators

Gilead Sciences acquires Immunomedics 21 for cash and debt

Bristol Myers Squibb acquires

MyoKardia for cash

Thermo Fisher Scientific offers to acquire 11.5 Qiagen for cash

Johnson \& Johnson acquires Momenta 6.5 for cash

Gilead Sciences acquires Forty Seven for cash

Sanofi acquires Principia for cash

Illumina is to acquire Grail for cash and stock, pending regulatory review

Merck acquires VelosBio for cash

Bayer acquires Asklepios to broaden cell 2.0 and gene therapy expertise

Gilead acquires MYR and its Hepcludex (bulevirtide) to treat chronic hepatitis delta virus
Table 4 | Size of major biotech markets

\begin{tabular}{ll} 
Country & Market size (\$ billions) \\
\hline United States & 480 \\
China & 140 \\
Japan & 80 \\
Germany & 50 \\
\hline
\end{tabular}

Source: Julius Bär

$\$ 4.9$ billion acquisition of Forty Seven in March 2020-one of the year's largest merger and acquisition (M\&A) transactions (Box 3). Magrolimab is in phase 3 trials for myelodysplastic syndrome, where it has breakthrough designation. Toxicity-in particular, anemia-has been challenging for the class; lemzoparlimab is designed to minimize binding to normal red blood cells and does not require a priming dose. This could give it an edge, according to Morningstar's Lee.

This year's licensing deals look richer still. Novartis in February 2021 forked out $\$ 650$ million up front for US, European and Japanese rights to Beijing-headquartered BeiGene's tislelizumab ( $a$ humanized IgG4 mAb targeting PD-1), after its own candidate, spartalizumab (an IgG4 humanized $\mathrm{mAb}$ whose program was acquired from the purchase of CoStim Pharmaceuticals in 2014), stumbled in a phase 3 melanoma trial last September. Tislelizumab is in trials in a range of cancers and combination regimens and is one of three in-house developed compounds that BeiGene sells in China. The other two drugs are the small-molecule poly(ADP-ribose) polymerase (PARP) inhibitor pamiparib and the BTK inhibitor Brukinsa.

The same month, Coherus BioSciences moved beyond its core biosimilars business to pay $\$ 150$ million up front, with a further $\$ 380$ million in potential milestones, for Shanghai-based Junshi Biosciences' PD-1 drug toripalimab. Toripalimab, a humanized IgG4 $\mathrm{mAb}$, was the first PD-1-targeting antibody to be approved in China (it was given conditional approval in December 2018), for second-line treatment of unresectable or metastatic melanoma. It is the subject of almost 30 global trials and received FDA fast track designation for mucosal melanoma in January. The treatment also has Breakthrough designation in advanced nasopharyngeal carcinoma, where the company began a rolling Biologics License Application submission at FDA in March 2021.

Deals among Chinese biotechs are another feature of this expanding sector. 
Table 5 | Top 10 licensing deals of 2020

\begin{tabular}{|c|c|c|c|}
\hline Companies & Headline & Date announced & $\begin{array}{l}\text { Up-front cash } \\
\text { (\$ millions) }\end{array}$ \\
\hline $\begin{array}{l}\text { Biogen (licensee) } \\
\text { Sage Therapeutics } \\
\text { (licensor) }\end{array}$ & $\begin{array}{l}\text { Biogen and Sage Therapeutics } \\
\text { partner to globally develop } \\
\text { and commercialize potential } \\
\text { breakthrough therapies in } \\
\text { depression and movement disorders }\end{array}$ & 27 November & 875 \\
\hline $\begin{array}{l}\text { Genmab (licensor) } \\
\text { AbbVie (licensee) }\end{array}$ & $\begin{array}{l}\text { Genmab grants AbbVie rights to } \\
\text { co-develop and commercialize } \\
\text { bispecific antibody products } \\
\text { outside the US and Japan and share } \\
\text { commercialization responsibilities in } \\
\text { the US and Japan }\end{array}$ & 10 June & 750 \\
\hline $\begin{array}{l}\text { MorphoSys (licensor) } \\
\text { Incyte (licensee) }\end{array}$ & $\begin{array}{l}\text { MorphoSys grants Incyte exclusive } \\
\text { rights outside the US to develop } \\
\text { and commercialize MorphoSys's } \\
\text { tafasitamab to treat blood cancers } \\
\text { and rights to co-commercialize the } \\
\text { product in the US for } \$ 900 \text { million } \\
\text { up front }\end{array}$ & 13 January & 750 \\
\hline $\begin{array}{l}\text { Roche (licensee) } \\
\text { Blueprint Medicines } \\
\text { (licensor) }\end{array}$ & $\begin{array}{l}\text { Blueprint Medicines grants Roche } \\
\text { exclusive rights to pralsetinib to } \\
\text { treat non-small-cell lung cancer, } \\
\text { thyroid cancers and solid tumors } \\
\text { outside the United States and } \\
\text { Greater China }\end{array}$ & 14 July & 675 \\
\hline $\begin{array}{l}\text { Myovant Sciences } \\
\text { (licensor) } \\
\text { Pfizer (licensee) }\end{array}$ & $\begin{array}{l}\text { Myovant Sciences and Pfizer partner } \\
\text { to develop and commercialize } \\
\text { Orgovyx (relugolix) in oncology } \\
\text { and women's health in the US and } \\
\text { Canada }\end{array}$ & 28 December & 650 \\
\hline $\begin{array}{l}\text { Seattle Genetics } \\
\text { (licensor) } \\
\text { Merck \& Co. } \\
\text { (licensee) }\end{array}$ & $\begin{array}{l}\text { Seattle Genetics partners with } \\
\text { Merck to develop and commercialize } \\
\text { ladiratuzumab vedotin }\end{array}$ & 14 September & 600 \\
\hline $\begin{array}{l}\text { Biogen (licensee) } \\
\text { Denali Therapeutics } \\
\text { (licensor) }\end{array}$ & $\begin{array}{l}\text { Denali partners with Biogen to } \\
\text { develop and commercialize its } \\
\text { LRRK2 program for Parkinson's } \\
\text { disease and certain transport vehicle } \\
\text { platform-enabled programs for } \\
\text { neurodegenerative diseases }\end{array}$ & 6 August & 560 \\
\hline $\begin{array}{l}\text { Dragonfly } \\
\text { Therapeutics } \\
\text { (licensor) } \\
\text { Bristol Myers Squibb } \\
\text { (licensee) }\end{array}$ & $\begin{array}{l}\text { Dragonfly Therapeutics grants } \\
\text { Bristol Myers Squibb exclusive, } \\
\text { worldwide rights to develop } \\
\text { and commercialize Dragonfly's } \\
\text { interleukin-12 investigational } \\
\text { immunotherapy program }\end{array}$ & 17 August & 475 \\
\hline $\begin{array}{l}\text { uniQure (licensor) } \\
\text { CSL Behring (licensee) }\end{array}$ & $\begin{array}{l}\text { uniQure grants CSL Behring } \\
\text { exclusive, worldwide rights to } \\
\text { develop and commercialize } \\
\text { etranacogene dezaparvovec for } \\
\text { hemophilia }\end{array}$ & 24 June & 450 \\
\hline
\end{tabular}

27 partnership deals had up-front, committed cash of over $\$ 100$ million, more than double the number in 2019. Cancer dominated, but the pandemic drove infectious diseases into second place, replacing neurology, with 100 deals (compared to just 28 the year before). Source: BioCentury $\mathrm{BCIQ}$

In May 2020, BeiGene teamed up with Hutchmed to test tislelizumab with surufatinib and fruquintinib in various solid cancers.

\section{Hong Kong has Nasdaq in its sights} Some of China's most innovative biotechs, including I-Mab, Zai Lab, BeiGene and Hutchmed, have listed on Nasdaq to access specialist investors who, in Lee's words, "fully appreciate the global revenue potential of a differentiated CD47 molecule or a best-in-class checkpoint inhibitor." Nasdaq is also a favored destination for floating European biotech companies.

But China's domestic exchanges are fast offering an alternative and are becoming more welcoming to domestic biotechs. Since a 2018 rule change that allowed loss-making firms to list, Hong Kong's Stock Exchange has raised almost a quarter of the $\$ 54$ billion brought in by biotech IPOs globally, according to Dealogic, including over $\$ 6.4$ billion in 2020 biotech IPOs. The Hong Kong biotech index, whose top ten companies by weighting include Innovent, Akeso and WuXi AppTec, rose $50 \%$ in 2020, twice as much as the Nasdaq Biotech Index. Follow-on funding raised almost as much as IPOs last year in Hong Kong; Innovent's \$610 million got 2021 off to a strong start.

Not to be left behind, Shanghai in mid2019 launched its Star Market, mirroring Hong Kong and Nasdaq's lenient listing requirements. Unlike the Hong Kong market, it isn't open to foreign investors. But there's plenty of domestic money. "Enormous pools of capital in Asia need to be allocated. Biotech and technology are top of the list," says one local biotech CEO. A year after launch, the Star Market was second only to Nasdaq in the number of listing across all sectors, according to Statista. Tianjin-based vaccine company CanSino Biologics is dual-listed in Hong Kong and Shanghai.

For now, generalist and retail investors dominate China's markets. Encouraged by government support for the sector and newly aware of its importance, they like biotech's mix of me-too drugs, offering near-term revenues, and the possibility of innovation-driven rewards later. Average share prices among Chinese-listed biotechs rose $106 \%$ between the start of 2020 and 2021, according to a McKinsey study, compared with rises of $39 \%$ for biotechs listed in Europe and 37\% for those in the United States.

Yet Chinese biotech is, like its global counterparts, starting to attract a wider range of strategic investors. Hutchmed's PIPE funds came from private and growth equity investors, including the Canadian Pension Plan Investment Board, which runs a $\$ 379$ billion fund for the country's national pension plan. The Qatar Investment Authority was one of the biggest investors in Shanghai Henlius's 2019 IPO in Hong Kong. Investors based outside Asia are setting up in Shanghai and Hong Kong as the region's biotech sector matures. 


\section{Further to go}

There's talk of a bubble in Chinese biotech, just as there is in the United States. Chinese company valuations are "on the moon" according to one investment analyst. There is also political risk. Chinese-US relations have been strained by a trade war and growing mistrust around each side's strategic objectives. US authorities are worried about intellectual property and biomedical data theft by a totalitarian Chinese government that seeks iron-fisted control not only over its citizens' lives and rights but also its businesses' interests, closely monitoring drug prices and company returns.

Yet that same government is also expected to double healthcare spend as a percentage of gross domestic product (GDP) over the next decade, from its current $5-6 \%$. (In the United States healthcare spending is a massive $18 \%$ of GDP.) China is also slashing the prices of generics so it can encourage the sector to fund more innovative medicines. It is investing in biotech, as a limited partner in investment firms or by granting cheap land or interest-free loans. It also demands lower taxes from innovative companies than from others. Drug and clinical trial approvals are now much faster in China, with fast-track and priority reviews for products serving unmet needs, and acceptance of foreign trial data.

The country is also upgrading and updating its healthcare infrastructure and digital solutions, with internet consultations quadrupling over the past two years. China has weaker data collection and sharing laws than elsewhere. This is facilitating growth of an already thriving artificial intelligence sector, and these factors may give domestic companies an advantage in healthcare, especially given the possibility that health data from hundreds of millions of Chinese may be more readily available to train algorithms for new applications.

There are also missing pieces, however. China still relies heavily on original discoveries from Western markets, in part due to a lack of government investment in basic research. There are too few local entrepreneurs, too few tax breaks for investors, and technology transfer is underdeveloped. Patients abound, but there aren't enough clinicians to run trials.

Still, says Akeso's Xi, "the environment for innovation in China gets better every day." Hutchmed's Hogg shrugs off the geopolitical risk, too. "We're trying to bring innovation to patients. We're not making plastic toys."

\section{Melanie Senior}

London, UK.

Published online: 8 July 2021

https://doi.org/10.1038/s41587-021-00973-w

\section{Acknowledgements}

Additional reporting by Riku Lähteenmäki, Turku, Finland.

\section{Additional information}

Supplementary information The online version contains supplementary material available at https://doi. org/10.1038/s41587-021-00973-w. 